\title{
Values of Malayu Ethnics to Improve Ideal Personality West Kalimantan, Indonesia
}

\author{
Rustam $^{1}$ dan Hastiani ${ }^{2}$ \\ ${ }^{1,2}$ IKIP PGRI Pontianak, Faculty of Science Education, Guidance and Counseling Study Program
}

\begin{abstract}
This study to interpret the values of life Melayu ethnic as way of life, reinstill as a heritage of local cultural values to develop their ideal personality. The ideal personality is the hope to think globally without leaving local values that become regional identities. The study used a qualitative approach with structured hermeneutic types, the main source of the book Saprahan Adat Budaya Melayu, the validity system used by Triangulation. Values of ethnic Melayu are religious, civilized, friendship, unifying, ethnic harmony, soul heir, hardworking, friendship, authenticity, hospitality, and politeness. Values of Melayu as media bibliocounseling for guidance and counseling teachers.
\end{abstract}

Keywords

bibliocounseling, ideal personality and value of melayu

Article Received: 20 September 2020, Revised: 30 November 2020, Accepted: 18 December 2020

\section{Introduction}

Usually, Adolescence defines as a range of teenage ages that is instead of an important life which some physical, cognitive, emotional, and behavioral changes occur, including those are in attachment patterns that imply changes in emotional experiences about self, parents and friends of the same age. Adolescence is one of the most important periods in life in terms of developing self-esteem; an evaluation is carried out by an individual, and maintained. It expresses agreement or disagreement, and shows the extent to which an individual believes that he is capable, important, successful, and worthy. In short, selfesteem is a self-assessment of the worthiness that expressed in the individual's attitudes towards it (Mujiyati \& Adiputra, 2018; Verzeletti, Zammuner, Galli, \& Agnoli, 2016). Concluding from the phenomenon that was obtained through observation in the East Pontianak environment, changes in student behavior from generation after generation was free from the attitude of the ethnic Malays; students' attitudes were free from traditional values and moral messages.

An increased state of thought is only possible when individuals can assemble four psychological processes; assessing the situation and context, choosing a series of actions in acceptable norms, recognizing the importance of moral behavior rather than other considerations, and showing steadfastness to behave morally (Bélanger \& Corresponding, 2012). Currently, Adolescents are not in accordance with teaching instructions in matters of speaking ethics; do not show their politeness when talking to older people. Adolescent behavior has been separated from the traditional message conveyed by parents. Students live in luxury; this indicates the fading of the value of modesty or attitude of living frugally. The students have their own ways that make them forget about their social environment, so that their attention and habits are given to fulfill their own preferences. Maslow emphasized that every person has a motive in terms of self-actualization, and then biological and psychological needs which are expressed starting at the lowest level must be fulfilled, so that individuals can actualize themselves. This hierarchy is expressed with physiological needs, safety needs, the needs for belonging and love, the needs for appreciation and self-actualization (Bulut, 2018). There is a shift in values about politeness, being polite to older people, respecting and loving as parents at home. The adolescents build their identities during adolescence and the transition to adulthood, influenced by their condition depending on their family character and school environment. According to theory, identity is a coherent conception of oneself that is related to targets, values, and beliefs that we make to be strong commitments. In building their identity, young 
people need to solve a number of problems: job choices, the values they commit (religions, politics, ethnicities, etc.) and satisfying gender formation and identity section which is the chosen scenario desired, (Pérez-torres, Pastor-ruiz, \& Abarrou-ben-boubaker, 2018; Wojciechowska, 2015). It is not only related to the ethics of manners to parents, but the politeness of students wearing uniforms of neglect of the moral messages of parents and the responsibility of carrying out the dress code. As Muslims, we are circumcised to maintain cleanliness and to live neatly, because customary teachings are representations of religious studies so that all attitudes and behaviors are based on religious studies. The adolescents are aware of the meaning of veiling that the headscarf is not just a head covering. More than that, there is indeed meaning of the obligation to cover the aurat or part of body which may not be visible while performing a ritual for Muslim women. This is something that has not been consistently applied by the students. The basic moral values of human ecology are based on the interdependence between human and nature and the human need to live with each other that religious orientation and/or spirituality are the values of a micro system (Date \& Type, 1997). The students utilize internet media as a source and then excited to try and imitate negative behavior. High-technology devices (computers, tablets, and smartphones), with the increasing popularity of the internet from day to day, have led to digital games becoming a popular activity, especially among young people. Most messages related to personal identity are intended to transmit selfimpressions of YouTuber and self-impression relationship with gender identity, sexual orientation, and vocational identity. It is important to consider this new interrelation space to understand the development of young people's identities (Özgür, 2019). When someone learns by observing the behavior of others, then the individual will take it as a reference point of the model you want to emulate. The figures of friendly students, caring for other people around them have faded, are defeated by their attention to mobile phones. Hedonist among adolescents, consumptive behavior and following the trend of idol figures leave the original identity of adolescents. The adolescents are faced with the postmodern period, self-expression needs, and narcissism. Adolescence is characterized by identity tendency, Identity Confusion. Identity is the social position in the community, rights, responsibilities, targets of loyalty, agreement and certain codes and also justification for these rights, responsibilities, and loyalty (Jing, 2017). Positive identity search will lead to the development of the potential of teenagers towards better way, while negative identity search is usually expressed by the teenagers in the form of behavior such as fights, drug abuse, which leads to decrease in achievement (Mujiyati \& Adiputra, 2018). Identity is related to one's ownership of self-resolution, complex and available to regulate the attributes of individuals who can handle themselves and regulate themselves from others. In this case, it is a cognitive construction that can be used with more information about the person, and which is a great personal value for the individual. Traditional ideas that are self-made and central have been replaced by the definition of self-multiplicity that appears contextually and reflected by some individuals (Czerwi, 2017; Pilarska, 2017; Piotrowski, 2015). Religiosity in Traditional Contexts and Religiosity Secularization has proven to be a significant socio-cultural factor in predicting individual differences in various aspects of personality and behavior, determining certain values and attitudes, categorized as individualist or collectivist (Zarzycka \& Tychmanowicz, 2016). Identity formation is an important psychosocial task in adolescence, the identity is expressed in symbols of language, fashions, properties and actions of actors. The activity of individual every day is as a process of collecting and reproducing separate expectations. The people's hope can establish 'social power' and 'social structure' (Giddens, 1938). Identity is the social dimension of a person who can be intact or not, clearly attached to culture (Mappiare-AT.,2017). Confirmation of identity is very important in the era of high modernity. Lately, individuals experienced selfdilemmas. The counselee's identity can be reviewed in counseling of various aspects: (1) Gender, (2) Ethnicity, (3) Values/religious systems, (4) Social strata or socio-economic classes, (5) Educational and Jobs (Careers) pathways can be synchronized to "JENiS-PK". 


\section{Values of Melayu Ethnic to Improve Personality}

Ministerial Regulation No. 74 explains that local wisdom must be delivered and integrated into local content. This mandate confirms that education has an obligation to convey and study about local wisdom, in order to be able to see the potential of the tradition of local wisdom as a traditional message, moral message, and strength for forming the students' personality. Ministerial Regulation No. 74 in article 7, paragraph 1 also mandates that educational units can submit material proposals about local wisdom based on the analysis result of the natural environment context, socio-culture and identification of local content to District/City governments. Culture, a set of shared core values regulating behavior in certain societies can motivate someone to do it in their own way (Sutantoputri \& Watt, 2013). The importance of both traditions in interaction or communication process will result intercultural interactions which are then shared as a collective culture (Winarni, Purwandari, Lusa, \& Dadi, 2018). The belief in the value system owned by ethnic Malays symbolizes family, mutual cooperation with love, and togetherness in different philosophies of life "berat same dipikol, ringan same dijinjeng, bediri same tinggi, dudok same rendah" (King, 2017; Arpan, 2014).

Malay people obedient to the tradition that are hereditary carried out until now. It is the authenticity of the Malay tribe that is full of custom so that the nickname for Malays is "orang beradat or civilized people", doing everything according to "teaching point". Civilized people for the Malay society are individuals who understand the rules which may or may not be, those are according to the teaching of religion and parent's order. Besides that, it also actualizes in the attitude of daily living and makes them to be a healthy person in Malayness. Conversely, the people who are not civilized break the rules and take on prohibiting work that is not permissible in religious teachings and existing customary messages. So that the actualization of their attitude of life is close to falsehood as a human being and this makes the people unhealthy. Then, the social connection may be a basic human need and the main determinant of welfare. Therefore, for people who struggle to fulfill their basic needs, the amount of love they feel is more important for their happiness than whether this number feels right or not (Tamir, Schwartz, Oishi, \& Kim, 2017). Philosophically, the main values are contained in Saprahan integrate into the meaning of concern (Senaseb Sepenanggungan), togetherness value (Seadat Sepusaka Sepucuk Setali Darah), Decency value (Bercakap bersetinah berunding bersetabik), openness value (Seanak sekemahan) (King, 2017;Arpan, 2014). Symbolically, besaprah is sitting to eat together, sitting on the floor with laying the mat or long cloth in a row, and eating face to face with using five fingers without a spoon and fork (King, 2017; Arpan, 2014). Saprahan is not just about eating, but it has deep meaning that contains religious, moral and ethical messages. Saprahan, sitting cross-legged on the floor with long cloth, this signifies simplicity; the authenticity of Malays ethnic represents the distinctive characteristic of eastern culture (King, 2017).

\section{Guidance And Counseling Media}

Local wisdom that has the power to shape the personality of students is still not optimal. This also becomes an obstacle to optimize the role of guidance counseling for forming the student's personality according to the ideal expectations of Pontianak society. Consideration of diverse cultural background of students is the reason until now that there is no element of local wisdom. Researcher chose Bibliotherapy Media, which has been known by several names which are bibliocounseling, bibliopsychology, biblioeducation, biblioguidance, library therapy, biblioprophylaxis, tutorial group therapy, and literaterapy (John, 2014). Bibliocounseling which acts as a self-help, a book is a therapeutic agent to help students to understand themselves.

Overcoming personal affairs by providing relevant literature, the literature review is customized to the person, situation, and developmental needs at the right time. Bibliotherapy is the use of reading to create affective change, personality growth, and 
development. Bibliotherapy is the use of reading guided by therapeutic results in mind (Tanrikulu, 2011). Moreover, it can give stimulus to individual skills patterns (Saklofske \& Zeidner, 2009). Bibliocounseling media was used not only to open cognitive but also affective, in order to bring the students into readable situations. It made the students seemingly to be in the story and made the students understand and be able to take decisions.

\section{Method And Discussion}

The paradigm in this research was social constructivism, focused on the nature of changes that take place continuously and structured (Cottone, 2012; Cottone et al., 2005). The method in this research used qualitative approach, multilevel Hermeneutic type, analysis the text and context of Malay ethnic local wisdom, namely Saprahan. Qualitative research had many things to offer to counselors and psychotherapists in terms of gaining a new understanding of the therapeutic processes, and in facilitating the experiences of different participants in therapy, specifically for clients to be heard (McLeod, 2001, 1997). Find potential elements forming the identity of Pontianak youth. The validity systems used were triangulation, intersubjectivity validation, and peer review.

This Multilevel Hermeneutics Analysis strategy was conducted to compare opinions. Alvesson and Sköldberg (1994) were dimensions of understanding. Hermeneutic tradition in natural science could be understood when understanding the world, precisely when constructing meaning and interpretation (Age, 2011). The aim was to equate perceptions and interpretations of the results of researcher's interpretations to practitioners, those were Malay humanists, public figures who practice local wisdom, and Guidance and Counseling teachers while observing the atmosphere in educational institutions, then the atmosphere of Malay society in local practice, because this study adapted the values of the local wisdom of East Pontianak Malay ethnic.

These activities were the characteristic of the Multilevel Hermeneutics Analysis) strategy which combined between 'text and context' as a source of research data. The purpose was to capture data in an integrated, comprehensive and detailed manner in the research construct in order to obtain the 'essence of meaning'. Comparison the opinions of Guidance and Counseling experts, and colleagues had also done in order to place the similarity of views on the meaning of the research finding. The activity was done so that the intersubjectivity validation of the research findings found the point or agreement and also indicated the validity or acceptance. Moreover, validity as a source of knowledge was also carried out through discussion of opinions on users of Bibliocounseling media and the results of studies the local wisdom values of East Pontianak Malay that was Guidance and Counseling teacher at school. This research contributed to the scientific development of Guidance and Counseling in Pontianak, particularly, as well as Guidance and Counseling which can be integrated in Indonesian style.

\section{Findings and Discussions}

Bepinjam stage was the first stage in preparing Saprahan. At the stage of taking and dividing, this was where the value of hard work and social solidarity contained, all done on a sense of sincerity and affection for others without expecting the rewards. This stage also contained sincerity. The value contained in that belief was a simple way of life or simplicity, using all from nature. Mutual cooperation symbolized the strong meaning of togetherness, loyalty, caring and working together to help each other in goodness for the sake of mutual interest and many people concerns. This was what meant by the philosophy of "Orang Melayu berat same dipikol ringan same dijinjeng or Malays with the same weight as being lightly carried on the same hand".

Beramu stage, the purpose was preparing the establishment of Serapo those were tents and poles to sustain the tent. The message contained in beramu stage was the ability of individuals to locate or position themselves in the society environment. The examples of Bepinjam paccah belah stage were plate, basin, Angse spoon, round tray, frying pan, and glass. The moral messages of this stage were the honesty of the people in borrowing, and trust, caring, compassion in lending these tools, responsible for the integrity of 
the borrowed tools to the accuracy and caution in using the tools.

Begilling and Merancap stages, at this stage the neighbors arrived at the house where the Saprahan tradition was held, especially for the ladies. At this stage, there was a value of perseverance because in cleaning all the cooking ingredients taking a long time, depending on the number of ingredients to be processed. Accuracy in sorting and processing determined the proportion of seasonings used, separating the location of the main food and dessert ingredients.

Berkaut stage was the stage of arranging cooked food into the dish or saucer, side dishes into the bowl, then arranging a typical Malay cake in a dish and the water that had been mixed with spices such as clove and nutmeg those called Ae Serbat or Serbat Water. Before presenting the food menu, the presenters spread a white cloth stretching on a mat or rug that called Saprahan cloth (Usman and Isnawati, 2007). The messages contained in this stage were to respect the social status of others and respect the authenticity of Saprahan itself. Malay was synonymous with yellow symbolizing the sun, let the individual be a strong person, not easily shaken by anything, had a determination of faith so that it was not easy to influence the negative things.

This phase was ended by taking Ae Serbat or Ae Sepang out, drinking water was brought out at the end of the event as a sign that the procession is complete, so that the term of Ae Serbat or Ae Sepang was as the repellent water and the audiences were allowed to go home (Usman \& Isnawati, 2007). The value conveyed subtly but remained clear and firm, daring to make decisions. The individuals could be gentle and polite, but the others understood the subtle attitude that was conveyed. Not always display a rude attitude on both saying and acting, Malay people symbolize themselves with strength but it did not mean prioritizing violence. They who dared to make healthy decisions for goodness with logical considerations, not hesitant, and not depend on others.

Bebasok and Mulangkan Barang stage was the stage towards the end of the Saprahan tradition. The values of collaboration between young ladies and young gentleman in cleaning up the dirty tools through sharing the responsibility fostered a spirit of cohesiveness for good deed their jokes leaded to positive intimacy. Five fingers indicated the pillars of Islam those were the foundation in living a life as servants of God and as humans who lived together in society. At the same time, eating using hands were fulfilling the sunnah of the Messenger of Allāh, Muhammad SAW.

On the other hand, the five fingers signified five precepts in Pancasila as the life philosophy of Indonesian people. This meaning brought the people together on one occasion, not knowing the age of young or old, rich or poor united in the Saprahan tradition as the motto of Bhineka Tunggal Ika, united in diversity and establish friendship in diversity. Seating and seeing brothers and sisters in a row were as a Malay sign for respecting each other. The people who were elder such as the religious leaders, traditional leaders and regional officials sitting in front and led by a Paret head. Positioning such those roles, placing others according to the role of the society was not only about a matter of respect but also about ethics in society in order to obey the values of politeness.

\section{Conclusion}

Identification was needed to achieve a strong character in facing increasingly confusing era challenges. From the adolescence and onwards, the struggle of identity formation will get an identity crisis, a turning point in one's life that can strengthen or weaken the personality. The potential elements of local wisdom, Saprahan was the form of adolescent identity included religious identity, civilization, friendship, unifying, harmonious in ethnicity, soul of a physician, hard worker, sharing, assertiveness or strong soul, mutual cooperation, friendship, authenticity, friendliness and courtesy. It was needed Bibliocounseling media with local wisdom that could illustrate the patterns of thought and process of cultural internalization related to the control of the adolescents' lifestyles. The use of Bibliocounseling media could make the adolescents able to connect their own affairs to the situation in counseling services with local wisdom. Discussion of Bibliocounseling media that had self-identity theme processed on cognitive and affective, so that the adolescents gained the emotional experience. 


\section{Acknowledgements}

On this occasion the author would like to thank the parties involved. each process of data collection for the validity of the findings, the researcher discussed with the experts. in the end the researcher thanked the IKIP PGRI Pontianak institution for their moral and moral support. practitioners in high schools in East Pontianak sub-district. Mr. Arpan as a local saprahan practice informant, thanks for the time given, moral support and enthusiasm. Thanks also the researchers convey to the people of eastern Pontianak who have taken the time to discuss. provide information regarding the development of adolescent behavior, and ideal expectations for adolescent growth and development.

\section{References}

[1] Alvesson, M., \& Kärreman, D. (2011). Qualitative Research and Theory Development: Mystery as Method. https://doi.org/10.4135/9781446287859

[2] Arpan. 2014. Saprahan Adat Budaya Melayu Sambas. Dewan pengurus daerah Majelis Adat Budaya Melayu Kabupaten Sambas.

[3] Age, L.-J. (2011). Grounded Theory Methodology: Positivism, Hermeneutics, and Pragmatism Grounded Theory Methodology: Positivism, Hermeneutics , and. The Qualitative Report, 16(6), 15991615. Retrieved from https://nsuworks.nova.edu/tqr/vol16/iss6/8

[4] Bélanger, C. H., \& Corresponding, P. D. (2012). Moral Reasoning , Academic Dishonesty , and Business Students. International Journal of Higher Education, 1(1), 72-89. https://doi.org/10.5430/ijhe.v1n1p72

[5] Bulut, S. S. (2018). Obstacles to Selfactualization of College Students-The Case of Gazi Faculty of Education. 6(10), 2271-2279. https://doi.org/10.13189/ujer.2018.061026

[6] Cottone. (2012). Paradigms of Counseling and Psychotherapy. Missouri: Robert Rocco Cottone at Smashwords.
[7] Cottone, R., Glosoff, H., Kocet, M., Lee, C., Moll, ChristineGlosoff, H. L., Kocet, M. M., \& The, V. T. (2005). Highlights of the 2005 ACA Code of Ethics. Ethics, (December), 1$9 . \quad$ Retrieved from http://counselingoutfitters.com/vistas/vistas06/ vistas06.02.pdf

[8] Czerwi, M. (2017). The creation of a concept of one' $s$ own life by adolescents as a manifestation of subjectivity and autonomy. Polish Psychological Bulletin, 48(1), 28-37. https://doi.org/DOI - 10.1515/ppb-2017-0004 Maria

[9] Date, P. U. B., \& Type, P. U. B. (1997). Spirituality \& Religiosity as Factors in Adolescents' Risk for Anti-Social Behaviors and Use of Resilient Behaviors. ERIC.

[10] Giddens, A. (1938). Giddens, Modernity and Self-Identity. Modernity and Self Indentity, 100-123. Retrieved from https://biblio.csusm.edu/sites/default/files/rese rves/giddens_modernity_and_selfidentity_ocr.pdf

[11] Jing, W. (2017). A Research on the Influence of Contemporary Popular Music upon Youths , Self-identity. (c), 12-17. https://doi.org/10.7575/aiac.alls.v.8n.5p.12

[12] John, T. P. (2014). Using Books in Clinical Social Work Practice. In Using Books in Clinical Social Work Practice. https://doi.org/10.4324/9781315821719

[13] King, V. T. (2017). Asia in transition: Borneo studies in history, society and culture. In Asia in transition: Borneo studies in history , society and culture (Vol. 4). https://doi.org/DOI 10.1007/978-981-100672-2

[14] Mappiare-AT., 2017. Meramu Model Konseling Berbasis Budaya Nusantara :KIPAS (Konseling Intensif Progresif Adaptif Struktur). Pidato Pengukuhan Jabatan Guru Besar dalam Bidang Ilmu Budaya Remajang. Fakultas Ilmu Pendidikan, disampaikan pada siding terbuka senat Universitas Negeri Malang, 28 Febuari 2017.

[15] McLeod. (2001). Qualitative Research in Counselling and Psychotherapy. London and 
New Delhi: SAGE Publications • Thousand Oaks

https://doi.org/10.4135/9781849209663

[16] McLeod, J. (1997). Narrative and Psychotherapy . London: Sage Publications, 180 pages. Reviewed by. Sage Publications, $38-40$.

https://doi.org/10.4135/9781849209489

[17] Mujiyati, M., \& Adiputra, S. (2018). Influence of Peer Groups to The Self-Esteem of Lampung and Javanese Students. International Journal of Psychology and Educational Studies, 5(1), 15-22. Retrieved from

http://dx.doi.org/10.17220/ijpes.2018.01.003 (C)

[18] Özgür, H. (2019). Online Game Addiction Among Turkish Adolescents: The Effect of Internet Parenting Style. 7(1), 47-68. https://doi.org/10.17220/mojet.2019.01.004

[19] Pérez-torres, V., Pastor-ruiz, Y., \& Abarrou-ben-boubaker, S. (2018). YouTubers videos and the construction of adolescent identity. Comunicar, 55, 61-70. Retrieved from https://doi.org/10.3916/C55-2018-06 $\% 7 \mathrm{C}$

[20] Pilarska, A. (2017). Effects of self-concept differentiation on sense of identity: The divided self revisited again. Polish Psychological Bulletin, 48(2), 255-263. https://doi.org/DOI - 10.1515/ppb-2017-0029

[21] Piotrowski, K. (2015). Identity and markers of adulthood: the relationship between two constructs. Polish Psychological Bulletin, 44(2011), 254-265. https://doi.org/DOI -10.2478/ppb-2013-0029

[22] Saklofske, D. H., \& Zeidner, M. (2009). Treating Child and Adolescent Aggression Through Bibliotherapy (The Springer Series on Human Exceptionality). https://doi.org/10.1007/978-0-387-09745-9

[23] Sutantoputri, N. W., \& Watt, H. M. G. (2013). Attribution and Motivation: Gender, Ethnicity, and Religion Differences among Indonesian University Students. International Journal of Higher Education, 2(1), 12-21. https://doi.org/10.5430/ijhe.v2n1p12
[24] Tamir, M., Schwartz, S. H., Oishi, S., \& Kim, M. Y. (2017). The secret to happiness: Feeling good or feeling right? Journal of Experimental Psychology: General, 146(10), 1448-1459.

https://doi.org/10.1037/xge0000303

[25] Tanrikulu, I. (2011). Self-help books and bibliotherapy: Reflections for Turkey. Procedia - Social and Behavioral Sciences, 30, 1862-1866. https://doi.org/10.1016/j.sbspro.2011.10.361

[26] Usman dan Inawita. 2007. Khazanah Khas Juadah dan Saprahan Kota Khatulistiwa, Pontianak.

[27] Verzeletti, C., Zammuner, V. L., Galli, C., \& Agnoli, S. (2016). Emotion regulation strategies and psychosocial well-being in adolescence. Cogent Psychology, 3, 1-15. Retrieved from http://dx.doi.org/10.1080/23311908.2016.119 9294\%0Aself,

[28] Winarni, E. W., Purwandari, E. P., Lusa, H., \& Dadi, S. (2018). The Impact of Thematic Learning Integrated ICT in Tabot Bengkulu as Cultural Ceremony toward Social Interaction Knowledge in Elementary School. Asian Journal of Education and Training, 4(2), $70-74$. https://doi.org/10.20448/journal.522.2018.42.7 0.74

[29] Wojciechowska, J. (2015). Social participation, identity style and identity dimensions in late adolescence among students of three types of vocational schools. 44(2011), 310-321. https://doi.org/DOI 10.2478/ppb-2013-0034

[30] Zarzycka, B., \& Tychmanowicz, A. (2016). The Interplay between Religiosity and Horizontal and Vertical IndividualismCollectivism among Polish Catholic Students. Polish Psychological Bulletin, 47(3), 383-393. https://doi.org/DOI - 10.1515/ppb-2016-0045 